\title{
A Right to Die for Prisoners?
}

Dr Angelika Reichstein (Law School, University of East Anglia, Norwich, United Kingdom)

\author{
Abstract \\ Purpose:
}

This article will explore whether, although the State has a duty to protect prisoners, there should nevertheless be a right for prisoners to decide when and how they die.

Approach:

Utilising a utopian thought experiment, the article covers a series of interrelated issues: the aims of punishment, the functions of prisons, the rights of prisoners, and the responsibilities of the State towards inmates. While the article takes a European focus, it is of interest to a global audience, as the philosophical ideas raised are universally applicable.

Findings:

As the right to die advances in society, so should it advance for prisoners. Once assisted dying has been legalised, it should also be available for dying prisoners.

Originality:

The question has so far not been analysed in depth. With an ageing prison population, however, it is vital that we start engaging with the problems posed by an ageing and dying prison population.

Keywords: right to die, European human rights, prisoners' rights, punishment, resocialisation

\section{Introduction}


Death is a given. While we are aware that our days are limited, it is a truth we try not to dwell upon. As long as we are healthy and (relatively) young, it is easy to ignore. And when thoughts of mortality creep up we can try to push them aside with the hope of dying peacefully and without pain in our sleep, at the end of a long, fulfilled life. Sadly, few people experience this type of death. ${ }^{1}$ In order to alleviate suffering and/or to avoid an undignified death, some individuals prefer to end their lives self-determinately, either through suicide or through a form of assisted dying. However, while all European countries apart from Cyprus have decriminalised suicide, only four (Belgium, Luxembourg, the Netherlands, and Switzerland) permit some form of legal 'assisted suicide'.

The question whether prisoners should be granted a right to die raises three complex, interrelated questions. How far can society's interest in punishment go, where does the duty of the State to protect prisoners end, and what are the specific rights of prisoners? This last question leads to further ones: To what extent do and should prisoners have personal autonomy? What does 'dignity' mean in the context of prisoners' treatment? How 'dignified' should prisoners' treatment be?

This article is a utopian thought experiment. Few European jurisdictions are close to implementing a 'right to die' for citizens, and they are even further away from a 'right to die' for prisoners. But that does not mean we should not engage with the idea. When we engage in utopian thinking, considering what our society could and should look like, we can come across and highlight shortcomings and problems of the status quo. As Hedrén puts it:

Utopian thought has the potential to work as an impulse or a driving force, inspiring development activities at many levels. The more concrete the forms are that it takes, the more it will stimulate reflections on the opportunities and

\footnotetext{
1 "There is a major mismatch between people's preferences for where they would like to die and their actual place of death. Our research shows that around $70 \%$ of people would prefer to die at home, yet around $50 \%$ currently die in hospital" See https://www.dyingmatters.org/page/frequently-asked-questions, accessed 10 April 2019.
} 
shortcomings linked to what is conceived to be achievable measures and optional development paths. $(2009$, p. 221)

In Lawlandia's prison HMP Noplace, a new approach to prisoners' rights has been introduced. New prisoners proceed through reception and induction as usual, with only one difference: after a mental health assessment, those deemed 'healthy' are offered a cyanide pill and told that they have the choice to take that pill if ever they decide to die. Those not wanting to be resocialised, not wanting to sit through their punishment, not looking forward to life after prison now have a way out...

This question about a right to die for prisoners touches on a variety of issues: the extent of prisoners' rights, the purposes of punishment, the aims and functions of prisons, and the interrelationship between all three. As such, it is a timely and important issue to consider. This paper will argue that a blanket ban on a prisoner's right to die does not adequately respect the prisoner's right to dignified treatment.

The article is in five sections. First, the approaches towards a right to die in general and assisted dying in Europe in particular will be outlined, as well as the conflicting notions behind a right to die for prisoners. Second, the prisoners' rights will be considered, especially the retention of autonomy and dignity and the idea of resocialisation. Next, the idea of punishment will be investigated before turning to the State's responsibility towards prisoners and introducing two further complications, namely the vulnerability of the prisoner and the need for capacity when deciding over one's death. Lastly, it will be explored what a change in the law should look like. While the conflicting interests make the possibility of a right to die in prison even more problematic than a right to die for those who are not in prison, this should not keep us from tackling it. 


\section{Setting the Scene:}

\subsection{A Right to Die in Europe}

Over the past decades, assisted dying has been a hotly debated topic across Europe, due to its highly moral and sensitive nature and the rising recognition of a need for legal change. ${ }^{2}$ Even in the very few countries that have legalised assisted dying to date, the precise scope of assisted dying remains controversial.

If we accept the idea of the human being as autonomous and free, ${ }^{3}$ then he or she should also be free to make decisions about his or her own life, even if they are detrimental to health and even life. This idea is generally accepted in so far as patients are allowed to refuse treatment, even if that endangers or ends their lives. ${ }^{4}$ The logical next step would be accepting a right to die and a right to be helped to die when lacking the necessary physical capacity to end their lives in the way they desire. In theory, autonomous choices should be respected and active assisted dying would serve to maintain independence until death (Biggs, 2001, p. 105). According to Nietzsche ('Nietzsche on Death: From Thus Spoke Zara Thustra', 1972, p. 313) for example, we have the freedom to want to die at the right time. To him, death should be a free act, happening at a chosen, right time. Suicide, therefore is an option of human autonomy (Baumann, 2001, p. 294). Taking that thought further, if autonomy meant we were allowed to commit suicide, then it should also be available to those requiring assistance. As Battin put it,

\footnotetext{
2 See for example the debates in Parliament on various Assisted Dying Bills, e.g. Hansard Vol 658, Wednesday 10 March 2004; Hansard Vol 681, Friday 12 May 2006, Hansard Vol 755, Friday 18 July 2014. See also debates at the Deutscher Juristentag (German Jurists Forum), criminal law division, regarding a right to die and an Alternativentwurf (alternative draft) for a law regulating assisted dying in 1986 and 2005.

${ }^{3}$ Autonomy as a philosophical concept found different interpretation over the centuries. It started out being applied to the Greek city-state, denoting its independence. Its scope was then extended, initially by religious thinkers, to also cover humans. (See Dworkin, G, 1988). According to the libertarian view on autonomy, postulated by for example Mill and Singer, autonomy is the right to have own choices in life respected, and the duty not to interfere with those of others. (See Foster, 2009). According to Foster (2009), there are four ways in which the label autonomy is being used: in the Kantian sense of acting completely rationally, as the ideal of living a self-determined life, as a reason for constraint, and as an evaluation which determines whether respect is required.

${ }^{4}$ See for example Re B (Adult: Refusal of Medical Treatment) [2002] 2 All ER 449.
} 
"control of one's own death as far as possible is a matter of fundamental human rights" (1994, p. 165).

The main arguments against legalising assisted dying and recognising a right to die are the need to protect vulnerable members of society, the fear of a 'slippery slope' and the sanctity of life (see for example Dworkin R, 1993 and Jackson and Keown, 2012). The other side of the argument tends to focus on autonomy and dignity in arguing for the liberty to choose when and how to die (see for example Biggs, 2001 and McLean, 2007). It is vital to differentiate between autonomy and dignity and not to see them as interchangeable catchphrases. As will be seen below, both play a vital role in imprisonment.

A further complicating factor in legalising assisted dying is the fact that a wish to die, whether in prison or within society, is often seen as a symptom of a mental illness, requiring treatment in a psychiatric hospital. The view point is that no one without a mental illness would wish to die. ${ }^{5}$ However, a wish to die should not be simply dismissed as symptom of a mental illness but should be carefully and objectively examined by medical practitioners trained in that area. Furthermore, while wanting to die can be a symptom of a mental illness, it is problematic to instantly preclude anyone with a mental illness from receiving assistance in dying, as their suffering can be acute and unbearable, as well (see for example the case Haas $v$ Switzerland, application no. 31322/07).

Assisted dying has been decriminalised in different forms in only four European countries: Belgium, Luxembourg, the Netherlands and Switzerland. In Belgium, physician-assisted dying was legalised in $2002 .{ }^{6}$ A patient has the right to receive assistance in dying if they are

\footnotetext{
${ }^{5}$ Studies show that a vast majority of those committing suicides are in fact suffering of a mental health condition (see for example Cavanagh et al, 2003).

${ }^{6}$ Belgium has the most liberal approach when it comes to assisted dying. In 2014, the case of Frank van den Bleeken made it into national and European media, as the Belgian serial rapist and murderer asked for an assisted death. Frank van den Bleeken had been imprisoned for more than 30 years following convictions for rape and rape-murders. While in 2014 his wish to die had been granted by the Belgian minister of justice, this was cancelled in 2015 and he was moved to a psychiatric prison ward, awaiting referral to a specialist facility in
} 
"in a medically futile condition of constant and unbearable physical or mental suffering that can not [sic] be alleviated". ${ }^{7}$ Since 2014 , Belgium also has a law in place enabling euthanasia for children. There is no age limit in place, as long as the parents consent to the procedure. ${ }^{8}$ In Luxembourg, physician-assisted suicide and assisted dying were legalised in $2009 .{ }^{9}$ The patient has to be terminally ill and suffering unbearably, either from a mental or a physical health condition. In the Netherlands, the Penal Code was amended in 2002 to legalise physician-assisted dying and suicide in cases of lasting and unbearable suffering. ${ }^{10}$ In 2004 , the Groningen Protocol promoted the availability of assisted dying to children under the age of 12. As this is not a law, the Groningen Protocol does not give physicians legal protection. So far, physicians are protected from prosecution as long as they act in accordance with the protocol, but no black-letter law exists in this area. In the Swiss Penal Code, assisted suicide is only prohibited if it is carried out for 'selfish motives'. ${ }^{11}$ What is required is that the final act lies with the person wishing to die, meaning that they have to be able to take the deadly medication themselves (see for example Reiter-Theil et al, 2018).

As this highlights, there is not yet a general right to die. If assistance is required, this is only available in four European countries and only within more or less strict parameters. Apart from possibly in Belgium and the Netherlands, where access to assisted dying is based on unbearable suffering but not necessarily terminal illness, prisoners do not fall within those parameters, unless they are terminally ill. Excluding prisoners from access to assisted dying can be supported by various interests in imprisonment, like the need for punishment and the State's duty of care. However, this article will demonstrate why a prisoner should have a

\footnotetext{
the Netherlands. Van den Bleeken wished to die as he saw himself as a threat to society and did not want to be released, but equally could not stand the thought of remaining in prison. ${ }^{6}$ See http://www.telegraph.co.uk/news/worldnews/europe/belgium/11098247/Belgium-grants-murderers-requestfor-mercy-killing.html, and http://www.telegraph.co.uk/news/worldnews/europe/belgium/11327541/Belgianserial-rapist-will-not-be-euthanised-as-planned.html, accessed 26 February 2018.

7 The Belgian Act on Euthanasia of May, 28th 2002, Section 3, §1.

8 Act amending the Act of 28 May 2002 on euthanasia, sanctioning euthanasia for minors, 2014. Belgian Official Gazette, number 2014009093: 21053.

9 Loi du 16 mars 2009 sur l'euthanasie et l'assistance au suicide, Article 2.

10 Termination of Life on Request and Assisted Suicide (Review Procedures) Act, April 1, 2002.

11 Swiss Criminal Code 1942, Article 115.
} 
(limited) right to die to enable access to assisted dying, just like every individual with capacity who is not imprisoned should.

\subsection{Conflicting Issues in Imprisonment}

When we contemplate a right to die for prisoners, it is easy to think in polarised terms: either treat prisoners with the same dignity as all others are treated, and enable autonomous decisions with some limits based on loss of liberty but including a right to die, or restrict autonomy legitimately as a proper and inevitable result of imprisonment. And with that we already have two of the three competing interests: prisoners' rights and the idea of punishment. But there is a third component to complicate matters further, namely, the State's responsibility towards individuals under its care.

The main argument against giving prisoners a right to die is that imprisonment's first and foremost purpose is punishment - though it should be highlighted that imprisonment is seen as being the punishment itself, not as giving room for further punishments (see for example Paterson, 1951). Thus, what stands in the way of letting prisoners choose the time and manner of their own death, is society and the victims' interest in seeing an offender punished.

At the same time, prisoners do keep most of their human rights on imprisonment, bar the right to liberty and possibly other rights that might need to be restricted, which might, for example, be necessary in the name of security. ${ }^{12}$

One problem when thinking of a possible right to die of prisoners is that the failure to prevent a prisoner from committing suicide amounts to a human rights violation, as the State has neglected its duty towards the prisoner. This makes an autonomous death wish highly problematic.

12 For example, the right to privacy can be limited in searching cells and monitoring correspondence. 
The following sections will analyse each argument in turn, starting with the rights of prisoners. ${ }^{13}$

\section{The Rights of Prisoners}

\subsection{Imprisonment for Resocialisation}

There are generally two ways in which we can view imprisonment: retributivism, which will be considered below, and utilitarianism. Following a utilitarian approach, punishment has the aim of preventing reoffending through deterrence, incapacitation, and rehabilitation (see Easton and Piper, 2016, p. 8). Imprisonment then focuses more on the future of the offender (not reoffending), than on the past (the wrongdoing).

HMP Noplace in Lawlandia makes no attempts at rehabilitation. The prisoners are not offered any education, any training or any therapy, but they enjoy a certain 'freedom' in prison. In HMP Noplace, prisoners can chose their own mealtimes, have access to the sports facilities, showers, and a library whenever they want and can choose their cell partner.

While this approach by HMP Noplace in Lawlandia might seem appealing to some, given either the relative level of autonomy granted to prisoners or the incapacitation of the offender, it is doubtful how successful this approach would be in relation to most aims behind imprisonment - deterrence, punishment, and resocialisation. A mere focus on incapacitation does not seem sufficient as a rationale behind imprisonment.

The punishing element of a sentence - i.e., taking away someone's physical liberty - and retribution should not exist as the sole elements of imprisonment. In order to ensure a dignified existence in prison, the aim of resocialisation has to be present. As stated by

\footnotetext{
${ }^{13}$ Due to the word restraints of this article, the arguments will only be briefly introduced to highlight the complexity of the problem.
} 
McCorkle and Korn, “'resocialisation' implies changes in group memberships” (1954, p. 88). For this to be possible, prisoners need to be provided with a number of opportunities to help achieve the aim. Be that the starting point of a structured day-to-day life, offers of therapy, treatment for medical conditions, or work and leisure activities.

Resocialisation can be seen as an aspect of rehabilitation (see for example Canton, 2017, pp. 102ff). While rehabilitation can generally encompass a variety of aspects, including reform and penance (Martufi, 2018, p. 673), resocialisation focuses on social integration. As Rotman stated, it aims to "reintegrate [the prisoner] into society as a useful human being" (1990, p. 6). Rehabilitation is, on the one hand, a right the prisoner has. This is a view stressed for example by the ECtHR in its jurisprudence on prisoners' rights (see for example Martufi, 2018). At the same time, it is an interest the State pursues in order to prevent prisoners reoffending (see for example Lewis, 2005, p. 123).

Resocialisation can only work if the prisoner actually wants to become a 'functioning member of society' or change their group membership; nobody can be forced to participate in programs aimed at resocialisation. Still, it is an aim the State has to follow. Resocialisation is strongly connected to viewing the prisoner as a fellow human being with rights, upholding their dignity and strengthening their autonomy.

\subsection{Autonomy}

Despite being deprived of their liberty, prisoners retain personal autonomy in prison. Naturally, not all rights can be retained, nor can a full level of autonomy, as imprisonment has more aims than just forcing a prisoner to live in a more confined setting, such as for example penance. Nonetheless, there are basic rights that remain. 
Initially, the idea of a prisoner retaining any level of autonomy might seem ludicrous. After all, autonomy can be seen to be an aspect of liberty and liberty is automatically, visibly, and purposefully forfeited in imprisonment. However, physical liberty is only one element of autonomy; in order for a dignified existence in prison, other elements of autonomy need to be upheld. This can take the form of choosing who to associate with during times in the courtyard, being able to take part in parkrun if it is being offered within the prison, deciding when to shower, and who to call. All these decisions - and many more - are an element of upholding individual autonomy within the prison walls. This level of autonomous decisionmaking is vital for upholding one's identity within prison. Despite forfeiting physical liberty and having to live in accordance with strict prison rules, other liberties should remain.

One of the most fundamental questions when it comes to living one's life is how we wish to end it. Most of us will wish to live it until its natural end but that is not true for everyone. Many of us wish to have the option of deciding when our life has nothing more to offer or has become so unbearable that we would rather end it. Based on the retention of autonomy as part of their human rights, this is a freedom prisoners should retain.

In addition to a prisoner's autonomy, what needs to be upheld at all costs is the prisoner's dignity.

\subsection{Dignity}

Dignity as an international legal concept dates back to the Universal Declaration of Human Rights, however, its origins as a legal concept can be said to go back to 1789 , at the domestic (French) constitutional level (see Dupré, 2013, p. 117). After the Second World War, dignity began to appear in the newly emerging international human rights documents (and national constitutions, like that of Germany) as a reaction to the atrocities of the war (see Chapman, 
2011, p. 5). While the lack of definition of dignity leads to plenty of criticism concerning its use, ${ }^{14}$ according to Chapman (2011, p. 5) and McCrudden (2008, p. 678), said lack helped in that every State involved in drafting and applying the documents could agree to it and then fill it with their own meaning.

While dignity is difficult to define, we accept that every human being possesses dignity, regardless of status, health, mental capacity, age, or other arbitrary criterion. Based on equal human rights, and the fact that dignity is the foundation of those rights, everyone should have their dignity equally protected. What is required is the protection of dignity "even in situations where the law is at its most forceful and its subjects at their most vulnerable" (Waldron, 2012, p. 218).

Dignity is a vital element in imprisonment. The dignity of a prisoner is easily threatened - by lack of privacy, the potential of degrading treatment by prison staff, the lack of activity to keep oneself occupied, to name just a few. Some would even go as far as claiming that "the entire process of prison is designed to destroy the last remnants of the dignity of the individual” (Singer, 1972, p. 669). The preamble to the European Prison Rules (EPR) 2006 stresses that:

$[\mathrm{T}]$ he enforcement of custodial sentences and the treatment of prisoners necessitate taking account of the requirements of safety, security and discipline while also ensuring prison conditions which do not infringe human dignity and which offer meaningful occupational activities and treatment programmes to inmates, thus preparing them for their reintegration into society.

\footnotetext{
${ }^{14}$ See for example McCrudden (2008: 655), who claimed that "the use of 'dignity', beyond a basic minimum core, does not provide a universalistic, principled basis for judicial decision-making in the human rights context, in the sense that there is little common understanding of what dignity requires substantively within or across jurisdictions". See also Kuhse (2000: 74), stating that "[dignity] is a slippery and inherently speciesist notion, it has a tendency to stifle argument and debate and encourages the drawing of moral boundaries in the wrong places".
} 
This links directly to the first article of the EPR, which states that "All persons deprived of their liberty shall be treated with respect for their human rights". The UN's resolution on Basic Principles for the Treatment of Prisoners also includes dignity as a necessity in imprisonment: "All prisoners shall be treated with the respect due to their inherent dignity and value as human beings" (UN GA Resolution 45/111, para [1]).

When contemplating the dignity of prisoners, this is linked to, yet different from, autonomy. Being treated with dignity makes the retention of a level of autonomy necessary. In order to lead a dignified life, some control over one's existence is crucial. But dignity requires more than a certain degree of autonomy. What is required is the room to uphold one's identity, being recognised as an individual with needs and boundaries. This also requires minimising aspects of prison life that are deemed to be undignified.

Dignity is often used as an argument for the need to legalise assisted dying, in order to prevent an undignified existence or undignified death. When aiming at upholding dignity in prison, the issues surrounding a dignified death cannot be ignored. With an ageing prison population comes an increase in illnesses and potentially death. A dignified death of prisoners consequently becomes increasingly topical.

However, there are also other ways of seeing imprisonment. Usually, it is seen to be a combination of resocialisation, deterrence, protecting society from dangerous individuals, as well as the loss of physical liberty as punishment. This last element is the one that stands in starkest contrast to giving prisoners rights and freedoms and is, therefore, essential to consider when contemplating a right to die for prisoners.

\section{Imprisonment as Punishment}


Following retributivist theories (see for example Von Hirsch, 1976), imprisonment is punishment for the wrongdoing. A vital element is that punishment has to be seen to be done. As such it serves both the interest of the State and that of the victims. As Feinberg puts it,

Punishment is a conventional device for the expression of attitudes of resentment and indignation, and of judgments of disapproval and reprobation, either on the part of the punishing authority himself or of those 'in whose name' the punishment is inflicted. (1965, p. 400)

Consequently, the type and onerousness of sentence communicates censure in proportion to the seriousness of the offence. Allowing or facilitating a prisoner's suicide undermines or even negates the expressive function of punishment.

In HMP Noplace, prisoners are not only not offered means to rehabilitate themselves, they are furthermore stripped of as many rights and freedoms as possible, to ensure that the fact that imprisonment is a punishment is felt by the prisoners on a daily basis, as well as being communicated to the outside world. There are no visiting hours, let alone conjugal visits, no right to speak to the outside world via telephone, no right to vote and no right to a meaningful pastime.

The case for restricting prisoners' rights in the name of punishment is compelling, but that cannot guide the entire structure and aims of prison life or the nature of the State's obligations towards prisoners. This paper will argue that while punishment is a vital element of imprisonment, achieved through the forfeiting of physical liberty, other factors can override this after a certain period of time, giving the prisoner more autonomy to make fundamental decisions over his or her life.

Based on a retributive view of imprisonment, one of the main issues with allowing a prisoner to die is that it undermines the aims of punishment for wrong doings. We do not want them to 
take an easy way out, cutting their punishment short. While dying of a natural death or through violence at the hand of someone else might also cut the sentence short, this is different than having the option of cutting it short oneself, as it is a non-voluntary death. Retributivism demands that punishment must be proportionate to the wrong doing. Connected to that, or seen as an aspect of it, is the idea that punishment has to be seen (see Skillen, 1980). One of the underlying ideas is that "retributive suffering' [...] can express and promote human responsibility" (Skillen, 1980, p. 523). Furthermore, it can be argued, that in contrast to the other goals of punishment - deterrence, incapacitation, and rehabilitation retribution is "the sole penal rationale concerned exclusively with doing justice" (Pugsley, 1979, p. 381). Through punishment, retributivism seeks to address the injustice that had been caused by the offender. As individuals are responsible for their behaviour, actions or omissions that go against the codes of a society require punishment (see Pugsley, 1979, p. 398). The idea is not inflicting punishment, i.e. taking away someone's physical liberty, to achieve a greater good, like deterrence or resocialisation, but inflicting punishment in proportion to the offence. According to Kant, this means treating the offender not as an object, but as a subject (see Kant, 1965, pp. 99-109). Furthermore, through retributive punishment, the laws and values of a society find affirmation (see Pugsley, 1979, p. 402). Consequently, imprisonment cannot actively be cut short: the timespan needed for retribution has to be fulfilled. A voluntary death would, therefore, take part of the retribution away.

But is that really how it is? Is being dead taking an easy way out? If we see imprisonment purely as a punishment, then yes. This is also an argument against the death penalty: execution actually stops the pain that the offender is meant to endure by way of punishment. A lot of prisoners serving a life sentence might prefer death. Punishment through being imprisoned consists in denying them the choice: denying them the opportunity to forego pain. That is also important if we see punishment as a form of penance: 
The penance theory informs us that punishment is a communicative act directed at the offender as a rational, autonomous agent. Punishment aims to convince him that his conduct deserves moral blame, that he should repent and restore his damaged relations with the community. (Lipkin, 1988, p. 89)

What the idea of penance presupposes is the prisoner as an autonomous, rational agent. Penance alone is not enough to justify imprisonment (see Lipkin, 1988, p. 94), nevertheless it is an additional element of imprisonment as punishment.

If we see imprisonment as a means to rehabilitate and re-socialise, then punishment is not necessarily the principle purpose of imprisonment. Imprisonment in order to turn the prisoner into a law-abiding member of society (again) only works when the prisoner actually wishes for this to happen. Alternatively, he will simply 'do time' without any gain apart from society feeling reassured that he is being punished. Admittedly, this reassurance is needed, as public confidence in criminal justice is important and it is inherent in our notions of justice that someone should suffer in response to blameworthy behaviour.

In addition to the punishing element of imprisonment, we need to consider the State's role in imprisonment, especially its duty to protect individuals under its care.

\section{State's Duty to Protect: No Voluntary Death in Prison}

The duty of States to safeguard prisoners from harm arises from the prisoner's state of vulnerability.

Lawlandia has strict mechanisms in place to protect the inmates in HMP Noplace. Prisoners have to undergo a monthly mental health screening, and have to report back about the other 
inmates' behaviour. Cells are designed not to give the opportunity to do harm to oneself, and no metal cutlery or tools are available to the prisoners.

A reason behind preventing suicides in detention is that prisoners are vulnerable and in need of protection by the State. Admittedly, removing someone from their known environment and their support network, in addition to all the specifics of imprisonment, ${ }^{15}$ is likely to impact negatively on mental wellbeing. Being isolated from the outside while at the same time living in close proximity to complete strangers is a challenging setting.

It is hard for prisoners to maintain their mental health and dignity when they are forced to defecate in front of strangers and eat in a lavatory. It is hard for prisoners - particularly for those who have experienced abuse as a child - not to be distressed by regular physical searches, or the less frequent but more intrusive strip searches which are part of maintaining security. (Rickford and Edgar, 2003, p. 26)

Vulnerability in prison can have a variety of causes including personal incapacities, lack of a support network, and a disadvantaged social status (see for example Mechanic and Tanner, 2007). While these do not necessarily render every individual experiencing them vulnerable, they can cause or heighten the sense of being vulnerable. As Mechanic and Tanner stated, "[v]ulnerability involves several interrelated dimensions: individual capacities and actions; the availability or lack of intimate and instrumental support; and neighbourhood and community resources that may facilitate or hinder personal coping and interpersonal relationships" (2007, p. 1222). The vulnerability of prisoners is not just due to the fact of being incarcerated, instead they "share multiple vulnerabilities, with large overrepresentation of racial minorities, people with mental illnesses, and people with little education and

\footnotetext{
${ }^{15}$ Confinement in a small space, lack of individuality, lack of meaningful tasks, etc.
} 
unstable work histories" (Mechanic and Tanner, 2007, p. 1224). Studies show that in prison $72 \%$ of male inmates have at least two mental health issues (Rickford and Edgar, 2003, p. 79).

\subsection{Vulnerability}

Even if there is no vulnerability in the individual as a precondition, it can arise out of the conditions of imprisonment, like the aggression and violence in prison leaving one to feel unsafe (see Ricciardelli et al, 2015, p. 496). In a study carried out by Ricciardelli et al (2015, p. 498) one of the findings was that a continuous risk of physical violence led to feelings of vulnerability. Additionally, the general lack of control creates vulnerability in that there is no stability or foreseeability as to what will happen the next day, week, month, or year (see Ricciardelli et al, 2015, p. 499). Focusing on the mental aspect of lack of autonomy, the study found that it can lead to anxiety and further the general vulnerability (see Ricciardelli et al, 2015, p. 504). Furthermore, some groups of prisoners are especially vulnerable. For example, according to the Harris Review, "all young adults in custody are potentially vulnerable. This vulnerability is the result of a combination of their lack of maturity, their life experiences and their experiences in custody, particularly around the support they receive" (Harris and Browne, 2016, p. 41). As the State is inflicting this specific situation on an individual, the State is also responsible for their general wellbeing, keeping prisoners healthy, and protected from additional suffering.

In addition to the mental health issues which can become more severe in prison, based on the added vulnerability, the State is under a duty to protect prisoners from their own rash wish to die once imprisoned. As a governor of a high security prison stated, many prisoners state to 
prefer death over the prison sentence they are facing. ${ }^{16}$ After a while, though, prisoners become accustomed to the reality of prison life and the wish to die subsides. A prison governor in Switzerland told the story of one of his inmates, who tried committing suicide at an early stage of his sentence. Years later, he stressed how glad he was it had not succeeded. ${ }^{17}$ This demonstrates why giving a general right to die to prisoners, and allowing or even enabling suicides in prison, is not desirable. The drastic change to the prisoner's life, by being catapulted out of ordinary life into a strictly confined and highly regulated setting, where the individual relinquishes not just freedom, but additional liberties, and in fact aspects of their individuality, causes a very real kind of vulnerability.

\section{Now What?}

Lawlandia's approach to a prisoner's right to die, by giving every 'healthy' prisoner in HMP Noplace a cyanide pill to take at their heart's desire, proves problematic. While it acknowledges the autonomy of the prisoner, as well as the need for the prisoner to have the mental capacity to make the decision, it only does so at the entry into the prison system. It thus ignores the problem of the effect imprisonment has on the individual, by increasing vulnerability and as such the duty of the State to protect those in its custody. Furthermore, it does not acknowledge the fact that an initial wish to die when entering prison most often subsides once the prisoner has adjusted to life in prison. A general right to die, therefore, does not seem feasible.

In Lawlandia's prison HMP Idealplace, a new approach to prisoners' rights has been introduced. If a prisoner is suffering unbearably or is terminally ill and/or dying, receiving

\footnotetext{
${ }^{16}$ Interview with a governor of a category A prison in England as part of a project funded by a Leverhulme/British Academy small research grant.

${ }^{17}$ Interview with a governor of a high security prison in Switzerland as part of a project funded by a Leverhulme/British Academy small research grant.
} 
assistance in dying within the prison walls has become a possibility as an alternative to being transferred to a hospice. The assistance is being carried out within the prison walls, but by physicians who generally practice outside of prison. The same safeguards apply as outside of prison, including strict assessments by at least two physicians and psychiatrists to determine the capacity of the prisoner and the voluntary nature of the request.

For assisted dying to be available in prison, once it has been generally legalised, specific additional safeguards have to be in place. As for non-prisoners, the voluntary nature of the wish for assistance has to be carefully established. Also, the unbearable suffering has to be determined by medical practitioners from outside the prison, to avoid potential abuse. Furthermore, the final act should be carried out in another setting than within the prison walls, be that a hospice or an assisted dying clinic, to eliminate the danger of the prison environment influencing the prisoner's decision, as well as for transparency reasons. What should also be avoided is using assisted dying as a cheaper alternative to dying in a hospice. The prisoners' wishes in this regard have to be upheld, based on the prisoners' right to have their dignity respected.

\section{Conclusion}

As has been established, a right to die for prisoners is a utopian thought.

Nevertheless, as the right to die advances in society, so should it advance for prisoners. Once assisted dying has been legalised, it should also be available for dying prisoners. This would uphold the need for the State to protect the prisoner, while at the same time acknowledging their dignity by enabling a dignified death.

What has to be achieved first is a general right to die, enabling everyone to choose death over life. This should then be extended to a limited right to die in prison, making assisted dying 
available in cases of unbearable suffering. This is required to protect the prisoners' dignity in a highly sensitive moment of life.

Whether in freedom or in prison, we all deserve to die with as much dignity as possible. 


\section{References}

Battin, M. (1994), The Least Worst Death, OUP, Oxford.

Baumann, U. (2001), Vom Recht au den eigenen Tod. Die Geschichte des Suizids vom 18. Bis zum 20. Jahrhundert in Deutschland, Verlag Hermann Böhlaus Nachfolger, Weimar.

Biggs, H. (2001), Euthanasia, Death with Dignity and the Law, Hart, Oxford.

Canton, R. (2017), Why Punish? An Introduction to the Philosophy of Punishment, Palgrave McMillan, London.

Cavanagh, J.T. et al (2003), "Psychological autopsy studies of suicide: a systematic review", Psychological Medicine, Vol. 33, pp. 395-405.

Chapman, A. R. (2011), "Human Dignity, Bioethics and Human Rights", Amsterdam Law Forum, Vol. 3, pp. 3-12.

Dupré, C. (2013), “Constructing the Meaning of Human Dignity: Four Questions”, in: McCrudden, C. (Ed.), Understanding Human Dignity, OUP, Oxford, pp. 113-121.

Dworkin, G. (1988), The Theory and Practice of Autonomy, CUP, Cambridge.

Dworkin, R. (1993), Life's Dominion. An Argument about Abortion and Euthanasia, HarperCollins, New York.

Easton, S. and Piper, C. (2016), Sentencing and Punishment. The Quest for Justice, (4 ${ }^{\text {th }}$ edn.), OUP, Oxford.

Feinberg, J. (1965), “The expressive function of punishment”, The Monist, Vol. 49 No. 3, pp. $397-423$.

Foster, C. (2009), Choosing Life, Choosing Death. The Tyranny of Autonomy in Medical Ethics and Law, Hart, Oxford. 
General Assembly United Nations (1990), UNGA Resolution 45/111, Basic Principles for the Treatment of Prisoners, 14 December 1990.

Harris, T. and Browne, D. (2016), "Vulnerability of Young Adults in Custody: The Harris Review Case for increased support”, Prison Service Journal, Vol. 226, pp. 37-42.

Harris, T. and the Harris Review Panel (2015), The Harris Review: Changing Prisons, Saving Lives Report of the Independent Review into Self-inflicted Deaths in Custody of 18-24 year olds, Crown, London.

Hedrén, J. (2009), "Shaping sustainability: Is there an unreleased potential in utopian thought?”, Futures, Vol. 41 No. 4, pp. 220-225.

Jackson, E. and Keown, J. (2012), Debating Euthanasia, Hart, Oxford.

Kant, I. (1965), The Metaphysical Elements of Justice, Ladd, J. (translated), Bobbs-Merrill, Indianapolis.

Kuhse, H. (2000), “Is There a Tension Between Autonomy and Dignity?”, in Kemp, P., Rendtorff, J. and Johansen, N.M. (Eds.), Bioethics and Biolaw. Vol II. Four Ethical Principles, Rhodos, Copenhagen, pp. 61-74.

Lewis, S. (2005), "Rehabilitation: Headline or footnote in the new penal policy?", Probation Journal, Vol. 52 No. 2, pp. 119-135.

Lipkin, R. (1988), "Punishment, Penance and Respect for Autonomy", Social Theory and Practice, Vol. 14 No. 1, pp. 87-104.

Martufi, A. (2018), "The paths of offender rehabilitation and the European dimension of punishment: New challenges for an old ideal?", Maastricht Journal of European and Comparative Law, Vol. 25 No. 6, pp. 672-688. 
McCorkle, L.W. and Korn, R. (1954), "Resozialisation Within Walls", The Annals of the American Academy of Political and Social Science, Vol. 293 No 1, pp. 88-98.

McCrudden, C. (2008), "Human Dignity and Judicial Interpretation of Human Rights", European Journal of International Law, Vol. 19 No. 4, pp. 655-724.

McLean, S. (2007), Assisted Dying: Reflections on the Need for Law Reform, Routledge, London.

Mechanic, D. and Tanner, J. (2007), "Vulnerable People, Groups, and Populations: Societal View", Health Affairs, Vol. 26 No. 5, pp. 1220-1230.

(1972), "Nietzsche on Death: From 'Thus Spoke Zara Thustra"”, Omega - Journal of Death and Dying, Vol. 2 No. 4, pp. 313-317.

Paterson, A. (1951), Paterson on Prisons. Being the collected papers of Sir Alexander Paterson, Muller, London.

Pugsley, R. (1979), "Retributivism: A Just Basis for Criminal Sentences", Hofstra Law Review, Vol. 7 No. 2, pp. 379- 405.

Reiter-Theil, S. Wetterauer, C. and Frei, I.A. (2018), “Taking One's Own Life in Hospital? Patients and Health Care Professionals Vis-à-Vis the Tension between Assisted Suicide and Suicide Prevention in Switzerland". International Journal of Environmental Research and Public Health, Vol. 15 No. 6, p. 1272.

Ricciardelli, R., Maier, K. and Hannah-Moffat, K. (2015), "Strategic masculinities: Vulnerabilities, risk and the production of prison masculinities", Theoretical Criminology, Vol. 19 No. 4, pp. 491-513. 
Rickford, D. and Edgar, K. (2003), Troubled Inside: Responding to the Mental Health Needs of Men in Prison, Prison Reform Trust, London.

Rotman, E. (1990), Beyond Punishment: A New View of the Rehabilitation of Criminal Offenders. Greenwood Press, Westport.

Singer, R. (1972), "Privacy, Autonomy, and Dignity in the Prison: A Preliminary Inquiry Concerning Constitutional Aspects of the Degradation Process in our Prisons", Buffalo Law Review, Vol. 21 No. 3, pp. 669-716.

Skillen, A.J. (1980), "How to Say Things with Walls", Philosophy, Vol. 55 No. 214, pp. 509523.

Von Hirsch, A. (1976), Doing Justice: The Choice of Punishments: Report of the Committee for the Study of Incarceration, Hill and Wang, New York.

Waldron, J. (2012), “How Law Protects Dignity”, Cambridge Law Journal, Vol. 71 No. 1, pp. 200-222. 